\title{
Sandaracinus amylolyticus gen. nov., sp. nov., a starch-degrading soil myxobacterium, and description of Sandaracinaceae fam. nov.
}

Correspondence
Rolf Müller
rolf.mueller@helmholtz-hzi.de

\author{
Kathrin I. Mohr, ${ }^{1}$ Ronald O. Garcia, ${ }^{2,3}$ Klaus Gerth, ${ }^{1}$ Herbert Irschik ${ }^{1}$ \\ and Rolf Müller ${ }^{1,2,3}$
${ }^{1}$ Department of Microbial Drugs, Helmholtz Centre for Infection Research (HZI), Inhoffenstraße 7, D-38124 Braunschweig, Germany
${ }^{2}$ Department of Microbial Natural Products, Helmholtz Institute for Pharmaceutical Research Saarland (HIPS) - Helmholtz Centre for Infection Research (HZI), Saarland University, Campus C2 366123 Saarbrücken, Germany
${ }^{3}$ Department of Pharmaceutical Biotechnology, Saarland University, Campus C2 366123 Saarbrücken, Germany

\begin{abstract}
A novel starch-degrading myxobacterium designated NOSO $-4^{\top}$ (new organism of the Sorangiineae strain 4) was isolated in 1995 from a soil sample containing plant residues, collected in Lucknow, Uttar Pradesh, India. The novel bacterium shows typical myxobacterial characteristics such as Gram-negative, rod-shaped vegetative cells, swarming colonies, fruiting body-like aggregates and bacteriolytic activity. The strain is mesophilic, strictly aerobic and chemoheterotrophic. Based on $16 \mathrm{~S}$ rRNA gene sequences, NOSO $-4^{\top}$ shows highest similarity (96.2\%) with the unidentified bacterial strain O29 (accession no. FN554397), isolated from leek (Allium porrum) rhizosphere, and to the myxobacteria Jahnella thaxteri (88.9\%) and Chondromyces pediculatus (88.5\%). Major fatty acids are $\mathrm{C}_{17: 1} 2-\mathrm{OH}, \mathrm{C}_{20: 4} \omega 6$ (arachidonic acid), and the straight-chain fatty acids $C_{17: 0}, C_{15: 0}$ and $C_{16: 0}$. The genomic DNA $G+C$ content of the novel isolate is $66.8 \mathrm{~mol} \%$. It is proposed that strain NOSO $-4^{\top}$ represents a novel species in a new genus, i.e. Sandaracinus amylolyticus gen. nov., sp. nov., but also belongs to a new family, Sandaracinaceae fam. nov. The type strain of the type species, S. amylolyticus sp. nov., is NOSO $-4^{\top}\left(=\right.$ DSM $53668^{\top}=$ NCCB $\left.100362^{\top}\right)$.
\end{abstract}

Myxobacteria are non-motile rod bacteria that have characteristic gliding movement on solid surfaces and form fruiting bodies. They are commonly isolated under aerobic and mesophilic conditions from soils, dung of herbivores, bark of trees and rotting woods. Myxobacteria are a known source of structurally complex bioactive secondary metabolites (Wenzel \& Müller, 2009; Weissman \& Müller, 2010; Gerth \& Müller, 2005; Reichenbach \& Höfle, 1999), making them industrially and pharmaceutically attractive for many therapeutic applications. In the past decade, unusual myxobacterial taxa have been discovered that represent the moderately thermophilic (Gerth \& Müller, 2005) and 'halophilic' (Iizuka et al., 2003; Fudou et al., 2002) groups. The discovery of the anaerobic group (Sanford et al., 2002) and some strains that may possibly represent the facultative anaerobes (Garcia et al.,

The GenBank/EMBL/DDBJ accession number for the 16S rRNA gene sequence of strain NOSO- $4^{\top}$ is HO540311.

Three supplementary figures and five supplementary tables are available with the online version of this paper. 2009b) suggest that myxobacteria are diverse in nature. Many of these bacteria show the remarkable feature of aggregation under nutrient-limiting conditions to develop species-specific fruiting bodies, with various degrees of complexity. During fruiting body morphogenesis, vegetative cells are transformed into desiccation-resistant myxospores, which allow the myxobacteria to survive under unfavourable environmental conditions (Shimkets et al., 2006). Although phenotypic characteristics are expressions of the genotype, they are unstable and may change or be lost under artificial growth conditions (Shimkets et al., 2006; Garcia et al., 2010).

Myxobacteria can be distinguished from other bacteria by their homophyletic clustering in the Myxococcales (Deltaproteobacteria) based on 16S rRNA gene sequence analyses (Shimkets \& Woese, 1992; Spröer et al., 1999; Garcia et al., 2010) and, recently, on fatty acid/phylogeny correlation (Garcia et al., 2011). To date, the names of three suborders, six families, 21 genera and 53 species have been validly published and these numbers are expected to 

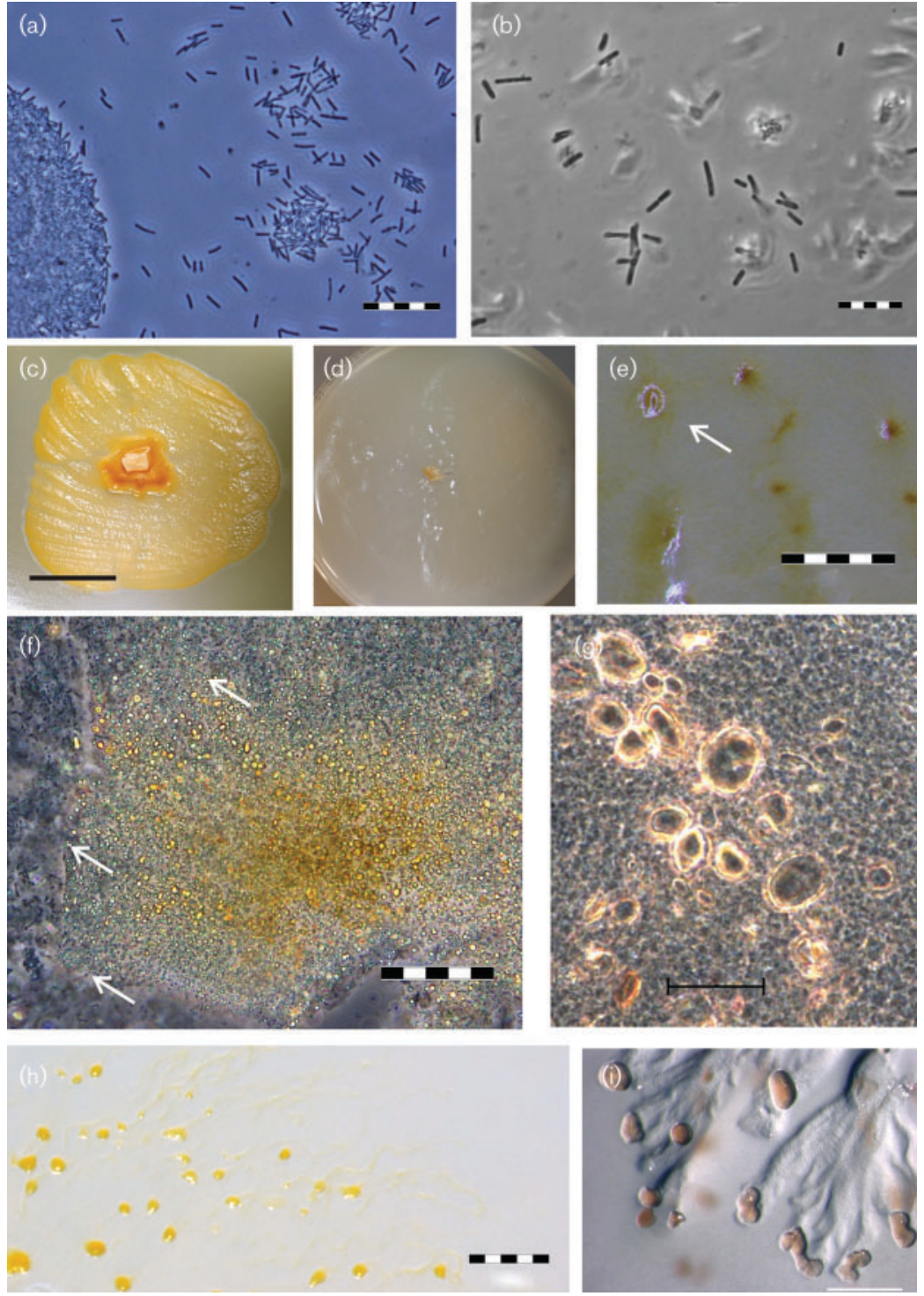

Fig. 1. Photographs showing the morphology of strain NOSO- $4^{\top}$. Phase-contrast photomicrographs of vegetative cells $(a-b)$ on $\mathrm{CY}$ agar after 4 weeks of incubation at $30{ }^{\circ} \mathrm{C}(\mathrm{a}$; bar, $20 \mu \mathrm{m}$ ), and in CY/H broth (b; bar, $10 \mu \mathrm{m}$ ). Swarming colonies after 5 weeks of growth at $30{ }^{\circ} \mathrm{C}(\mathrm{c}-\mathrm{d})$ on P-agar (c; bar, $10 \mathrm{~mm}$ ) and on $\mathrm{VY} / 2$ agar (d; plate diameter, $90 \mathrm{~mm}$ ). Fruiting body-like aggregates after 8 weeks of incubation (e-f) on CY medium (e; arrow; bar, $500 \mu \mathrm{m}$ ) and after crushing, pointing to the myxosporelike cells (f; arrows; bar, $50 \mu \mathrm{m}$ ). Phase-contrast photomicrograph of cell aggregates taken from 3-week-old CY/H broth culture (g; bar, $20 \mu \mathrm{m}$ ). Swarm and fruiting body-like aggregates of Jahnella thaxteri PI $\mathrm{t} 4^{\top}$ (=DSM $14626^{\mathrm{T}}$ ) (h; bar, $1 \mathrm{~mm}$ ) and Polyangium spumosum $\mathrm{Pl} \mathrm{sm}^{\top}$ $\left(=\mathrm{DSM} 14734^{\mathrm{T}}\right.$ ) (i; bar, $\left.500 \mu \mathrm{m}\right)$ on VY/2 agar (both 3-week-old cultures). increase after the complete description of yet-to-bepublished novel isolates (Garcia et al., 2010). Based on phylogenetic and chemotaxonomic data, we propose a new taxon for strain NOSO $-4^{\mathrm{T}}$.

NOSO- ${ }^{\mathrm{T}}$ was isolated at the HZI [former Gesellschaft für Biotechnologische Forschung (GBF)] in 1996 from a greybrown soil sample containing plant residues, collected in 1995 in a botanical garden in India. The strain was purified and isolated according to standard methods (Reichenbach \& Dworkin, 1992) and maintained in CY/H-medium [1.0 g defatted soy flour, $1.0 \mathrm{~g}$ glucose, $4.0 \mathrm{~g}$ starch (Cerestar), 1.5 g yeast extract, $1.5 \mathrm{~g}$ casitone, $1.0 \mathrm{~g} \mathrm{CaCl}_{2} \cdot 2 \mathrm{H}_{2} \mathrm{O}$, $0.5 \mathrm{~g} \mathrm{MgSO}_{4} .7 \mathrm{H}_{2} \mathrm{O}, 0.008 \mathrm{~g}$ iron-EDTA, $11.8 \mathrm{~g}$ HEPES, $\mathrm{pH}$ 7.3]. All media recipes used in this study are expressed as per litre distilled water and all were supplemented after autoclaving with $1 \mathrm{mll}^{-1} 500$-fold diluted vitamin solution (Schlegel, 1992), except for VY/2 (Shimkets et al., 2006). All agar and broth $(250 \mathrm{ml}$ Erlenmeyer flask containing $100 \mathrm{ml}$ medium, rotary shaken at 160 r.p.m.) cultures were incubated for $1-4$ weeks at $30{ }^{\circ} \mathrm{C}$, unless specified otherwise.

The morphology of vegetative cells was analysed by phasecontrast microscopy (Olympus BX51), measured using the image analysis software 'cell' (Olympus), and photographed using a DP20 Olympus camera. Cells of NOSO $-4^{\mathrm{T}}$ were slender rods with rounded ends (Fig. $1 \mathrm{a}, \mathrm{b}$ ), measuring 0.7-1.0 $\mu \mathrm{m}$ wide and 3.0-6.4 $\mu \mathrm{m}$ (mean $4.5 \mu \mathrm{m}$ ) long. Cells of this morphology are of the Nannocystineae- and Sorangiineae-type. In comparison to members of the latter, exemplified by Phaselicystis flava $\mathrm{SBKo} 01^{\mathrm{T}}$ (Garcia et al., 2009b) and Byssovorax cruenta By c2 ${ }^{\mathrm{T}}$ (Reichenbach et al., 2006), cells of the novel isolate were shorter. The orange colour of NOSO- $4^{\mathrm{T}}$ vegetative cells was evident after centrifugation of broth culture grown in CY (Shimkets et al., 2006), CY/H, M (Gerth \& Müller, 2005), P (Garcia et al., 2009b) and E [4.0 g skimmed milk, $4.0 \mathrm{~g}$ defatted soy 
flour, $2.0 \mathrm{~g}$ yeast extract, $10.0 \mathrm{~g}$ starch (Cerestar), $1.0 \mathrm{~g}$ $\mathrm{MgSO}_{4} .7 \mathrm{H}_{2} \mathrm{O}, 11.8 \mathrm{~g}$ HEPES, $0.008 \mathrm{~g}$ iron-EDTA, $5 \mathrm{~g}$ glycerine, $\mathrm{pH}$ 7.4] media.

Swarming and fruiting body-like aggregates were observed on VY/2, P agar and CY medium (Shimkets et al., 2006), viewed under an Olympus SZX10 stereo microscope. The swarm colony produced on agar was dark-orange with shallow wave depressions on P (Fig. 1c) and light-orange in $\mathrm{CY}$. On VY/2 agar, thin and transparent colonies were produced (Fig. 1d), which were often barely recognizable. In addition, no radiating veins, ripples or penetrating swarm could be detected.

Fruiting body-like aggregates were sessile, irregular and sometimes appeared scattered on the agar. The aggregates were brownish-orange measuring $50-150 \mu \mathrm{m}$ in diameter, with no enclosing wall or sporangiole (Fig. 1e). These characteristics differ from the yellow-orange and reddish aggregates observed in Jahnella thaxteri $\mathrm{Pl} \mathrm{t} 4^{\mathrm{T}}$ and Polyangium spumosum $\mathrm{Pl} \mathrm{sm} 5^{\mathrm{T}}$, respectively. The latter usually developed cell mounds close to the swarm end, whereas in the former, development usually occurred over the veiny yellow colony. NOSO $-4^{\mathrm{T}}$ cellular aggregation, characterized by circular inversion at the top, usually developed after more than 8 weeks of incubation on CY agar. Refractive rod-shaped cells shorter than vegetative cells could be observed after crushing the cellular aggregates, which appeared to be myxospores (Fig. 1f). Since NOSO $-4^{\mathrm{T}}$ was isolated a year after it was collected (March 1995) from a soil sample dried for 6 months, it could be hypothesized that the novel strain developed a resistant stage. Myxobacterial myxospores are known to withstand desiccation conditions for years (Reichenbach et al., 2006; Garcia et al., 2009a). Since the myxospore-like cells did not germinate and yield swarm colonies after desiccation, it appears that they are at an immature stage, or probably not real myxospores. Moreover, the sporangiole-like aggregates (mean $15 \mu \mathrm{m}$ ) could also be found in $\mathrm{CY} / \mathrm{H}$ broth after 3 weeks of cultivation (Fig. 1g); however, these lacked myxospore-like cells.

Different genera of myxobacteria can be distinguished by their unique pigmentation. NOSO $-4^{\mathrm{T}}$ produced yellow to orange cell pigment in agar and broth media, which is suggestive of carotenoids. This differs from the intense blood-red colour of Byssovorax cruenta, the golden-yellow of Phaselicystis flava and the yellow-orange colour of Jahnella thaxteri (Fig. 1h). Polyangium spumosum $\mathrm{Pl} \mathrm{sm} 5^{\mathrm{T}}$ is distinctive for its reddish-brownish fruiting body and reddish-pink cell aggregates on its swarm edges (Fig. 1i). Several novel different carotenoids have been reportedly isolated in a strain of Polyangium fumosum (Jansen et al., 1995). Its occurrence in different genera and in different suborders (Shimkets et al., 2006) indicates that this pigment is common amongst myxobacteria.

The ability of NOSO- $4^{\mathrm{T}}$ to lyse micro-organisms was tested on water agar $\left(1.5 \mathrm{~g} \mathrm{CaCl}_{2} .2 \mathrm{H}_{2} \mathrm{O}, 1.5 \mathrm{~g} \mathrm{MgSO}_{4} \cdot 7 \mathrm{H}_{2} \mathrm{O}\right.$, $11.8 \mathrm{~g}$ HEPES, $18.0 \mathrm{~g}$ Bacto agar, $\mathrm{pH}$ 7.2) supplemented with $1 \mathrm{ml}$ vitamin solution using streaks of live bacteria (Escherichia coli, Klebsiella sp., Staphylococcus aureus, Micrococcus luteus, 'Nocardia flava'), yeasts (Saccharomyces cerevisiae, Candida albicans, Schizosaccharomyces pombe and Pichia anomala), filamentous fungi (Mucor hiemalis) and autoclaved Escherichia coli cells. Actively growing NOSO-4 ${ }^{\mathrm{T}}$ was inoculated in the middle of the crossed-streak microbial bait. Amongst the microbial prey tested, only the filamentous mould Mucor hiemalis, yeast Schizosaccharomyces pombe and acid-fast 'Nocardia flava' were not lysed; this could also be explained by the inability of the novel bacterium to grow in association with these micro-organisms. The ability of the novel bacterium to degrade bacteria and yeasts is not surprising (Table S1, available in IJSEM Online), as myxobacteria are regarded as notorious micropredators, scavengers and macromolecule decomposers of the natural environment (Rosenberg \& Varon, 1984; Shimkets et al., 2006). Its dependence on prey organisms as nutrient sources was evident in lean water agar medium in which no growth was observed.

No cellulose, chitin or agar degradation was observed after cultivation on standard media; however, strong starch hydrolysis was observed. Cellulose degradation was tested on Stan-21 agar (Shimkets et al., 2006) overlaid with filter paper (about $1 \mathrm{~cm}^{2}$ ) and on Cel-3 agar (Reichenbach \& Dworkin, 1992), whereas chitin degradation was performed on CT-7 agar (Reichenbach, 2006) and on synthetic $S$ medium (0.5 g $\mathrm{CaCl}_{2} .2 \mathrm{H}_{2} \mathrm{O}, 0.5 \mathrm{~g} \mathrm{MgSO}_{4} .7 \mathrm{H}_{2} \mathrm{O}, 0.06 \mathrm{~g} \mathrm{~K}_{2} \mathrm{HPO}_{4}, 0.008 \mathrm{~g}$ iron-EDTA, $11.8 \mathrm{~g}$ HEPES, pH 7.2) supplemented with $1 \%$ chitin. So far, only Sorangium cellulosum and Byssovorax cruenta of the myxobacteria are known to decompose cellulose, whereas chitin degradation occurs in some members of the suborder Cystobacterineae (Reichenbach, 2005). Agar degradation was tested on WA, CY, VY/2 and P media. To test for starch hydrolysis, the latter medium was used and the reaction was determined after flooding the 4week-old culture with $2 \mathrm{ml} 0.01 \mathrm{M}$ iodine solution. A clear zone around the colony indicated complete starch hydrolysis (Fig. S1); this appears to be a common phenomenon amongst myxobacteria (Shimkets et al., 2006; Reichenbach, 2005). All set-ups were incubated for 1 to 4 weeks.

NOSO $-4^{\mathrm{T}}$ vegetative cells were Gram-negative, and catalase- and oxidase-positive. Gram staining was tested using a Gram stain kit (Fluka, Sigma-Aldrich), catalase activity was determined using a drop of $3 \% \mathrm{H}_{2} \mathrm{O}_{2}$ (Madigan et al., 2001), and oxidase activity was tested with $1 \%$ tetramethylphenylenediamine (Kovacs, 1956). The swarm colony stained negative after flooding with Congo-red solution (McCurdy, 1969) on VY/2 agar, suggesting that the novel bacterium belonged to either Sorangiineae or Nannocystineae suborders. For determining antibiotic resistance, all antibiotics were filter-sterilized before they were added to a pre-cooled agar and the final concentration was adjusted to $50 \mu \mathrm{g} \mathrm{ml}^{-1}$. Interestingly, NOSO $-4^{\mathrm{T}}$ exhibited wide resistance to antibiotics when tested on CY and VY/2 agar. Having tested 14 antibiotics, NOSO $-4^{\mathrm{T}}$ was found to be sensitive to ampicillin, kasugamycin, bacitracin 
and oxytetracycline. Growth was moderate on polymyxin, spectinomycin, kanamycin, neomycin, hygromycin and trimethoprim. The isolate barely grew in medium containing gentamicin. Growth comparable to the negative control (without antibiotic) was observed on cephalosporin, fusidic acid and thiostrepton, indicating resistance to these antibiotics.

NOSO $-4^{\mathrm{T}}$ was mesophilic and grew in a narrow $\mathrm{pH}$ range. On CY and VY/2 agar inoculated with a small agar plug (approx. $5 \times 5 \mathrm{~mm}$ ), the novel isolate grew optimally at $30{ }^{\circ} \mathrm{C}$ as indicated by largest swarm diameter. Growth tolerance was observed at $18-44{ }^{\circ} \mathrm{C}$; no growth was observed outside these temperatures. The strain tolerated $\mathrm{pH}$ 5.5-8.5 and optimal growth was observed at $\mathrm{pH} 6.5-8.0$ on $\mathrm{CY}$ and $\mathrm{K}$ medium [2 g potato protein (Emsland Group), 8 g soluble starch, $4 \mathrm{~g}$ probion (single cell protein, Hoechst), $2 \mathrm{~g}$ yeast extract, $1 \mathrm{~g} \mathrm{CaCl}_{2} .2 \mathrm{H}_{2} \mathrm{O}, 1 \mathrm{~g} \mathrm{MgSO}_{4} \cdot 7 \mathrm{H}_{2} \mathrm{O}, 23.8 \mathrm{~g} \mathrm{HEPES}$, $8 \mathrm{mg}$ iron-EDTA, $\mathrm{pH}$ 7.5]. No growth was seen at $\mathrm{pH} 5.0$ or above pH 9.5 (Table S2). Colony diameter was measured after 1-2 weeks of incubation.

The inability of NOSO $-4^{\mathrm{T}}$ to grow in $\mathrm{S}$ agar supplemented with $0.5 \% \mathrm{KNO}_{3}$ (electron acceptor), $0.5 \%$ starch or maltotriose (electron donor), and vitamin solution even after extended incubation (6 weeks) in an Anaerocult chamber (Merck) suggests its aerobic behaviour. Growth as indicated by colourless and extensive swarming was observed in an aerobic control set-up. To date, most of the cultured myxobacteria belong to the aerobic group (Shimkets et al., 2006) except for members of the genus Anaeromyxobacter (Sanford et al., 2002) and some novel isolates, which probably represent facultative anaerobes (Garcia et al., 2009a, 2010).

As a preliminary test for the development of a synthetic medium, Casitone (C) (1.0 g Bacto Casitone, $1.0 \mathrm{~g}$ $\mathrm{MgSO}_{4} \cdot 7 \mathrm{H}_{2} \mathrm{O}, 1.0 \mathrm{~g} \mathrm{CaCl} 2.2 \mathrm{H}_{2} \mathrm{O}, 0.008 \mathrm{~g}$ iron-EDTA, 11.8 g HEPES, pH 7.2) and Casamino acids (C medium, with casitone substituted by Casamino acids) media were both used as carbon and nitrogen sources and, in parallel, supplemented with different sugars (maltose, maltotriose, sucrose, starch and glucose) as additional carbon sources. Casitone and Casamino alone showed moderate growth, whereas supplementation with maltotriose and starch gave significant growth; hence, these sugars were chosen as the carbon source in S medium (Table S3).

To determine the nitrogen requirement of the novel strain in synthetic $S$ medium, different organic and inorganic sources were tested. Nitrogen and carbon sources were filter-sterilized and added to a final concentration of 0.5 and $0.25 \%$, respectively. Starch was also incorporated into the medium ( $0.5 \%$ concentration) and was sterilized by autoclaving. The test was performed in $100 \mathrm{ml} \mathrm{S}$ medium containing $1 \mathrm{ml} \mathrm{l}^{-1}$ vitamin solution. After a week of incubation in a rotary shaker $\left(160\right.$ r.p.m. at $\left.30{ }^{\circ} \mathrm{C}\right), 5 \%$ of the culture inoculum was transferred into corresponding fresh new medium. Using this approach, NOSO- $4^{\mathrm{T}}$ was subcultivated three times. Growth was assessed by cell density determination. In contrast to other micropredatory myxobacteria, the novel bacterium did not appear to be dependent on amino acids for its growth. In general, the presence of starch and maltotriose as carbon sources yielded luxuriant growth when supplemented with all nitrogen sources, except for urea, which did not stimulate growth of the isolate. The requirement of these sugars as sole carbon source needed for growth has also been observed in Corallococcus coralloides (Irschik \& Reichenbach, 1985). Asparagine, glutamate and potassium nitrate were the best nitrogen sources, while starch and maltotriose served as carbon sources. No growth could be observed in other carbon sources (Table S3).

Vitamin dependence of the novel isolate was tested in $\mathrm{E}$ broth and performed in three two-fold passages. In each case, $100 \mu \mathrm{l}$ 500-fold concentrated vitamin stock solution (Schlegel, 1992) was added to $100 \mathrm{ml}$ broth in $250 \mathrm{ml}$ Erlenmeyer flasks. The vitamin solution, which comprised seven different components (in $\mu \mathrm{g} \mathrm{ml}{ }^{-1}$ : biotin, 2; nicotinic acid, 20; thiamine, 10; 4-aminobenzoate, 10; pantothenate, 5; pyridoxamine, 50; and cyanocobalamin, 20), was filter-sterilized and one component was omitted from each solution during the assay. Tests were performed for 1 week under shaking conditions (160 r.p.m.). E medium set-ups with complete vitamins, and those with only cyanocobalamin as the sole vitamin source were used as the positive controls, whereas the opposite vitaminand cyanocobalamin-free media were used as the negative controls. NOSO $-4^{\mathrm{T}}$ cultures were deep orange after three passages except in the vitamin- and cyanocobalamin-free set-ups (Fig. S2). Microscopic examination of the first passage revealed that in cells grown in cyanocobalaminand vitamin-free media, vegetative cells appeared fragmented, which indicates lysis. Vitamin dependence was clearly observed after the third passage where no growth could be detected in medium set-ups lacking cyanocobalamin and vitamin solution. NOSO $-4^{\mathrm{T}}$ cyanocobalamin dependency is not unusual; the requirement for this vitamin has also been determined in many Polyangium strains (Shimkets et al., 2006).

For fatty acid analysis, NOSO $-4^{\mathrm{T}}$ was cultivated on P-agar medium for 1 week at $30{ }^{\circ} \mathrm{C}$. The culture was harvested by scraping a loopful of cells. Fatty acid extraction, GC-MS analysis and identification were performed as described previously (Garcia et al., 2011) but the latter analysis was based on the updated version (v2.69) of the AMDIS (Automated Mass Spectral Deconvolution and Identification System) software [National Institute of Standards and Technology (NIST), Gaithersburg, MD]. Fatty acid amounts (\%) were calculated using the values obtained from the integrated signal. The major fatty acids identified were $\mathrm{C}_{17: 1} 2-\mathrm{OH}, \mathrm{C}_{20: 4} \omega 6$ (arachidonic acid) and the straight chain fatty acids $\mathrm{C}_{17: 0}, \mathrm{C}_{15: 0}$ and $\mathrm{C}_{16: 0}$ (Table S4). Besides arachidonic acid, trace amounts of the polyunsaturated $\gamma$ linolenic and homo- $\gamma$-linolenic fatty acids were found. The occurrence and distribution of these fatty acids have been explored extensively previously (Garcia et al., 2011). The 
designation of strain NOSO $-4^{\mathrm{T}}$ under the Sorangiineae is supported by the predominance of straight-chain fatty acids, as opposed to branched-chain fatty acids, and the presence of $\mathrm{C}_{17: 1} 2-\mathrm{OH}$. The latter fatty acid appears to be the biomarker for the Sorangiineae suborder (Garcia et al., 2011).

To analyse the DNA G $+\mathrm{C}$ content of NOSO $-4^{\mathrm{T}}$, actively growing cells were obtained from $\mathrm{M}$ broth culture (Müller \& Gerth, 2006) and genomic DNA was extracted by the salting-out method (Pospiech \& Neumann, 1995). The DNA G $+\mathrm{C}$ content of the novel bacterium was determined by HPLC after nuclease P1 digestion ( $\mathrm{Li}$ et al., 2003; Shimelis \& Giese, 2006). The DNA G $+\mathrm{C}$ of NOSO $-4^{\mathrm{T}}$ was $66.8 \mathrm{~mol} \%$, which was within the range described for myxobacteria (Shimkets et al., 2006).

For 16S rRNA gene amplification, genomic DNA was extracted from actively growing CY culture broth using the SpinPlant Mini kit (Invisorb; Invitek). The gene was amplified using the universal F27 and R1525 primers (Lane, 1991) added to the PCR mixture (JumpStartReady mix; Sigma-Aldrich) according to the supplier's protocol. PCR was conducted in a Master Cycler Gradient (Eppendorf) using the following conditions: initial denaturation of $5 \mathrm{~min}$ at $95{ }^{\circ} \mathrm{C}$; followed by 35 denaturing cycles at $94{ }^{\circ} \mathrm{C}$ for $30 \mathrm{~s}$, annealing at $52{ }^{\circ} \mathrm{C}$ for $30 \mathrm{~s}$ and extension at $72{ }^{\circ} \mathrm{C}$ for $120 \mathrm{~s}$; and final elongation at $72{ }^{\circ} \mathrm{C}$, $10 \mathrm{~min}$. The PCR products were analysed by electrophoresis in a $0.8 \%$ agarose gel, stained with Gel Star, and purified using the NucleoSpin Extraction kit (MachereyNagel). In addition to universal 16S rRNA gene primers, previously mentioned above, F945, R518 (Lane, 1991), F357 (Turner et al., 1999) and R1078 (Stackebrandt \& Liesack, 1993) primers were also used for sequencing, to assure that both nucleotide directions were covered. The consensus sequence was generated from forward and reverse sequences using Seq ManII and sequences were aligned using the ARB version 14.02.2005 database (http:// www.arb-home.de). The sequence was compared with NCBI database entries using the FASTA search tool (http:// www.ebi.ac.uk/Tools/sss/fasta/). Closely related organisms and myxobacterial sequences, representing different species, were imported into the ARB database. Only sequences without gaps and ambiguity were chosen. A distance matrix tree was constructed with 176 sequences comprising more than $1375 \mathrm{bp}$ using the neighbour-joining method (Saitou \& Nei, 1987) and Jukes-Cantor correction (Jukes \& Cantor, 1969). The topology of the phylogenetic tree was built by bootstrap analysis of 1000 operations. As recommended in ARB, no filter was used in bootstrapping. A maximum-likelihood tree was calculated with the AXML + fastDNAml tool provided by the ARB. An individual $50 \%$ conservation filter was calculated and applied (Ludwig et al., 2004). Only the type and representative myxobacterial strains, and clones of uncultured bacteria with highest similarity to the novel isolate were shown in the phylogenetic tree. Table S5 gives the strains and their corresponding 16S rRNA gene accession numbers used for the construction of the phylogenetic tree.
Based on the complete $16 \mathrm{~S}$ rRNA gene sequence, NOSO- $4^{\mathrm{T}}$ shows highest similarity $(96.2 \%)$ with the unidentified soil bacterial strain O29 (accession no. FN554397). The neighbour-joining tree revealed that NOSO $-4^{\mathrm{T}}$ occupied a novel position in the suborder Sorangiineae (Fig. 2), which was supported by a $100 \%$ bootstrap value. Its unique and separate branch in the phylogenetic tree was confirmed by the maximum-likelihood method (Fig. S3). Based on $4 \%$ phylogenetic distance and novel branching (Garcia et al., 2010), the novel isolate qualifies for the assignment to a novel taxon. Phaselicystidaceae was placed in a novel family based on $6 \%$ phylogenetic distance difference to Sorangium (Polyangiaceae). NOSO-4 ${ }^{\mathrm{T}}$ shows an even higher phylogenetic distance $(>11 \%)$ to its closest myxobacterial neighbour (Jahnella thaxteri). Its novel position in the phylogenetic tree, clustering with the clones of uncultured bacteria, and branching out from the two known Sorangiineae families (Polyangiaceae, Phaselicystidaceae) clearly indicate that NOSO $-4^{\mathrm{T}}$ represents a novel species in a new genus and family.

\section{Description of Sandaracinus gen. nov. Mohr, Garcia, Irschik, Gerth and Müller}

Sandaracinus (San.da.ra' ci.nus. Gr. adj. sandaracinos orangecoloured; N.L. masc. n. Sandaracinus referring to orangecoloured vegetative cells).

Vegetative cells are rod-shaped with blunt rounded ends (Sorangium-type). Cultures in nutrient-rich media are coloured yellowish-orange. Produce shallow and wavy agar depressions on P-agar. Scattered and sessile fruiting-bodylike aggregates on agar bear refractive myxospore-like cells, which are shorter than vegetative cells. The aggregates could also be found embedded shallowly in the agar. No sporangioles or walls cover the myxospore-like cells. In old cultures, sporangiole-like aggregates may be produced, measuring 50-150 $\mu \mathrm{m}$ wide and brownish-orange. Strictly aerobic, chemo-organotrophic, mesophilic, and oxidaseand catalase-positive. Agar is not liquefied. The phylogenetic position is in the suborder Sorangiineae, order Myxococcales. The type species is Sandaracinus amylolyticus.

\section{Description of Sandaracinus amylolyticus sp. nov. Mohr, Garcia, Irschik, Gerth and Müller 2012}

Sandaracinus amylolyticus (am.y.lo.ly'ti.cus. Gr. n. amylum starch; Gr. adj. lyticus dissolving; N.L. adj. amylolyticus, starch dissolving).

Exhibits all the characteristics of the genus in addition to the following. Vegetative cells are $0.7-1.0 \mu \mathrm{m}$ wide and about $4.5 \mu \mathrm{m}(3.0-6.4 \mu \mathrm{m})$ long. Colonies vary from intense orange to almost transparent in colour. Grows between 20 and $44{ }^{\circ} \mathrm{C}$; optimal growth is at $30{ }^{\circ} \mathrm{C}$. Cyanocobalamin is essential for growth. Tolerates $\mathrm{pH} 5.5-$ 9.5; optimum $\mathrm{pH}$ is 6.5-8.0. Bacteriolytic- and noncellulolytic type of nutrition. Yeast can also be degraded. Suitable carbon sources are glutamate, starch and maltotriose. In the presence of starch or maltotriose, good growth 
0.10

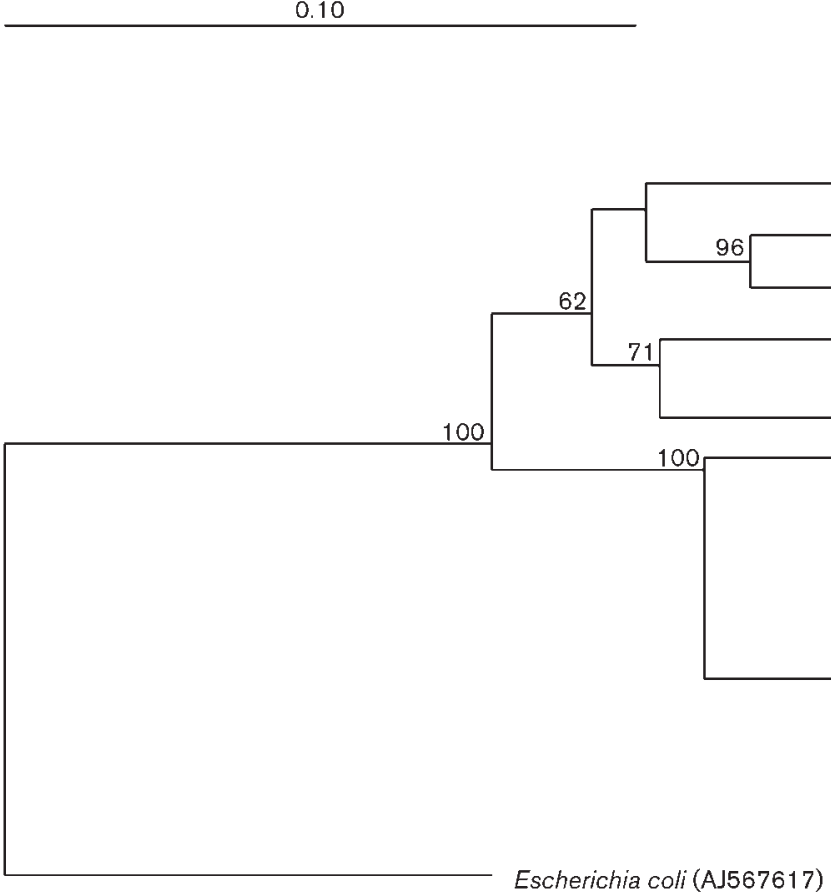

99 Chondromyces apiculatus DSM $14605^{\mathrm{NT}}$ (AJ233938) Chondromyces robustus DSM 14608 (A 233942) Chondromyces lanuginosus DSM 14631 (AJ233939) Chondromyces pediculatus Cm p17 (AJ233940)

$100 \quad 79 \square$ Byssovorax cruenta DSM 14553 ${ }^{\top}$ (AJ833647)

100 Phaselicystis hlava DSM 21295 (EU545827) Sandaracinus amylolyticus NOSO 4 ( $(\mathrm{HQ540311)}$ delta proteobacterlum O29 (FN554397)

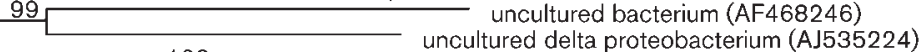
Haliangium ochraceum DSM 14365' (AB016470)
Kofleria flava DSM 14601' (AJ233944)

Enhygromyxa salina DSM $15217^{\prime}(\mathrm{NR}$ 024807)
Plesiocystis pacifica SIR-1 $1^{\top}(\mathrm{NR} 024795)$ Nannocystis exedens $\mathrm{Na} \mathbf{e}^{\top}$ (AJ233946)

Anaeromyxobacter dehalogenans ATCC BAA-258 (AF382396) Myxococcus fulvus Mx 428 (AJ233919)

(D. Myxococcus stipitatus DSM 14675 (D.118)

96 Pyxidicoccus fallax DSM $14698^{\top}$ (Da768123)

62 [ Myxococcus virescens Mx v76 (AJ233926) Myxococcus xanthus ATCC 25232 (DQ768 Corallococcus exiguus DSM 14696 (Da768121) Stigmatella aurantiaca DSM 7044 (GU207882)

- Archangium gephyra DSM $2261^{\top}$ (DO768106) Cystobacter minus DSM $14751^{\mathrm{NT}}$ (AD7683106)

98 Melittangium boletus Me b8 (AJ233908)

98 Cystobacter miniatus DSM $14712^{\top}$ (DO768111)

76[ Cystobacter velatus DSM 14718 (DO768115)

Cystobacter fuscus DSM $2262^{\top}$ (DQ768109)
Cystobacter ferrugineus DSM $14716^{\mathrm{NI}}($ AJ233901)

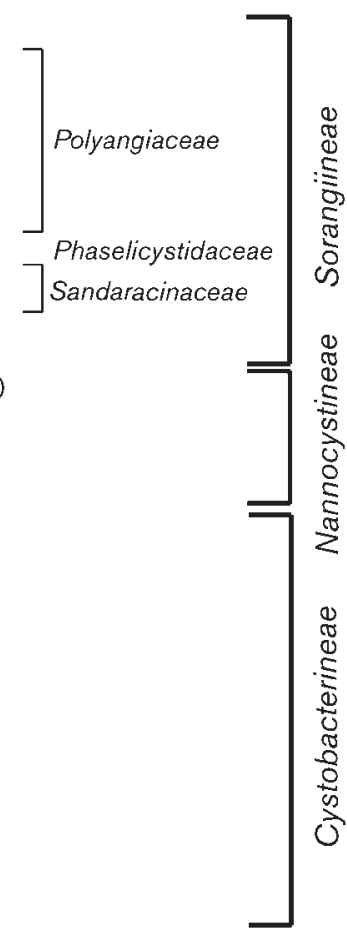

Fig. 2. Neighbour-joining tree of NOSO $-4^{\top}$ based on $16 \mathrm{~S}$ rRNA gene myxobacterial sequences. Only selected myxobacterial type strains and closest relatives of NOSO-4 ${ }^{\top}$ are shown. Numbers at the nodes indicate the bootstrap support based on 1000 replicates. Values $\geqslant 60 \%$ are shown. Bar, $10 \%$ estimated difference in the nucleotide sequences. 
is observed with potassium nitrate, L-glutamine, L-asparagine, L-arginine, L-aspartate, L-lysine and glutamate, whereas moderate growth is observed with ammonium sulfate. Exhibits good growth with glutamate as sole carbon and nitrogen source. Major fatty acids are $\mathrm{C}_{17: 1} 2-\mathrm{OH}$, $\mathrm{C}_{20: 4} \omega 6$ (arachidonic acid) and straight chain fatty acids $\mathrm{C}_{17: 0}, \mathrm{C}_{15: 0}$ and $\mathrm{C}_{16: 0}$. Produces polyunsaturated $\gamma$ linolenic and homo- $\gamma$-linolenic fatty acids.

The type strain is NOSO $-4^{\mathrm{T}}\left(=\mathrm{DSM} 53668^{\mathrm{T}}=\mathrm{NCCB}\right.$ $100362^{\mathrm{T}}$ ), isolated from a botanical garden in Uttar Pradesh, Lucknow, India. The DNA G $+\mathrm{C}$ content of the type strain is $66.8 \mathrm{~mol} \%$.

\section{Description of Sandaracinaceae fam. nov. Mohr, Garcia, Gerth, Irschik and Müller 2012}

Sandaracinaceae (San.da.ra.ci.na'ce.ae. Gr. adj. Sandaracinus type genus of the family; L. suff. -aceae ending to denote a family; Gr. pl. Sandaracinaceae the Sandaracinus family).

Soil myxobacterium. Vegetative cells are Gram-negative cylindrical rods with rounded ends. Swarm colonies on nutrient-rich media are orange, less distinctive and do not adsorb Congo-red stain. Cell aggregates contain refractive short rod cells with blunted ends. Bacteriolytic nutritional type. Does not degrade cellulose or chitin. The delineation of the family is primarily determined from the phylogenetic position based on 16S rRNA gene sequence and fatty acid profile. The type genus of the family is Sandaracinus.

\section{Acknowledgements}

We sincerely thank Dr Elke Lang, DSMZ, for valuable discussion and help finding the name of the strain. We are grateful to Dr Ritesh Raju for proofreading of this manuscript and to Ms Diana Telkemeyer for her excellent laboratory assistance and photography.

\section{References}

Fudou, R., Jojima, Y., lizuka, T. \& Yamanaka, S. (2002). Haliangium ochraceum gen. nov., sp. nov. and Haliangium tepidum sp. nov.: novel moderately halophilic myxobacteria isolated from coastal saline environments. J Gen Appl Microbiol 48, 109-115.

Garcia, R., Krug, D. \& Müller, R. (2009a). Discovering natural products from myxobacteria with emphasis on rare producer strains in combination with improved analytical methods. Methods Enzymol 458, 59-91.

Garcia, R. O., Reichenbach, H., Ring, M. W. \& Müller, R. (2009b). Phaselicystis flava gen. nov., sp. nov., an arachidonic acid-containing soil myxobacterium, and the description of Phaselicystidaceae fam. nov. Int J Syst Evol Microbiol 59, 1524-1530.

Garcia, R., Gerth, K., Stadler, M., Dogma, I. J., Jr \& Müller, R. (2010). Expanded phylogeny of myxobacteria and evidence for cultivation of the 'unculturables'. Mol Phylogenet Evol 57, 878-887.

Garcia, R., Pistorius, D., Stadler, M. \& Müller, R. (2011). Fatty acidrelated phylogeny of myxobacteria as an approach to discover polyunsaturated omega-3/6 fatty acids. J Bacteriol 193, 1930-1942.

Gerth, K. \& Müller, R. (2005). Moderately thermophilic myxobacteria: novel potential for the production of natural products isolation and characterization. Environ Microbiol 7, 874-880. lizuka, T., Jojima, Y., Fudou, R., Hiraishi, A., Ahn, J.-W. \& Yamanaka, S. (2003). Plesiocystis pacifica gen. nov., sp. nov., a marine myxobacterium that contains dihydrogenated menaquinone, isolated from the Pacific coasts of Japan. Int J Syst Evol Microbiol 53, 189-195.

Irschik, H. \& Reichenbach, H. (1985). An unusual pattern of carbohydrate utilization in Corallococcus (Myxococcus) coralloides (Myxobacterales). Arch Microbiol 142, 40-44.

Jansen, R., Nowak, A., Kunze, B., Reichenbach, H. \& Hofle, G. (1995). Four new carotenoids from Polyangium fumosum (myxobacteria): 3,3',4,4'-tetradehydro-1,1' $, 2,2^{\prime}$-tetrahydro-1,1' -dihydroxy- $\psi, \psi$ carotene (di-O-demethylspirilloxanthin), its $\beta$-glucoside and glucoside fatty acid esters. Liebigs Ann 1995, 873-876.

Jukes, T. H. \& Cantor, C. R. (1969). Evolution of protein molecules. In Mammalian Protein Metabolism, pp. 21-123. Edited by H. N. Munro. New York: Academic Press.

Kovacs, N. (1956). Identification of Pseudomonas pyocyanea by the oxidase reaction. Nature 178, 703.

Lane, D. J. (1991). 16S/23S rDNA sequencing. In Nucleic Acid Techniques in Bacterial Systematics, pp. 115-175. Edited by E. Stackebrandt \& M. Goodfellow. Chichester: Wiley.

Li, G., Shimelis, O., Zhou, X. \& Giese, R. W. (2003). Scaled-down nuclease P1 for scaled-up DNA digestion. Biotechniques 34, 908-909.

Ludwig, W., Strunk, O., Westram, R., Richter, L., Meier, H., Yadhukumar, Buchner, A., Lai, T., Steppi, S. \& other authors (2004). ARB: a software environment for sequence data. Nucleic Acids Res 32, 1363-1371.

Madigan, M. T., Martinko, J. M. \& Parker, J. (2001). Brock Mikrobiologie (translation of the 9th edn). Berlin: Spektrum Akademischer Verlag.

McCurdy, H. D. (1969). Studies on the taxonomy of the Myxobacterales. I. Record of Canadian isolates and survey of methods. Can J Microbiol 15, 1453-1461.

Müller, R. \& Gerth, K. (2006). Development of simple media which allow investigations into the global regulation of chivosazol biosynthesis with Sorangium cellulosum So ce56. J Biotechnol 121, 192-200.

Pospiech, A. \& Neumann, B. (1995). A versatile quick-prep of genomic DNA from gram-positive bacteria. Trends Genet 11, 217218.

Reichenbach, H. (2005). Order VIII. Myxococcales Tchan, Pochon and Prévot 1948, 398 ${ }^{\mathrm{AL}}$. In Bergey's Manual of Systematic Bacteriology, 2nd edn, vol. 2, pp. 1059-1072. Edited by D. J. Brenner, N. R. Krieg, J. T. Staley \& G. M. Garrity. New York: Springer.

Reichenbach, H. (2006). The genus Lysobacter. In The Prokaryotes: a Handbook on the Biology of Bacteria, 3rd edn, vol. 6, pp. 939-957. Edited by M. Dworkin, S. Falkow, E. Rosenberg, K. H. Schleifer \& E. Stackebrandt. New York: Springer.

Reichenbach, H. \& Dworkin, M. (1992). The myxobacteria. In The Prokaryotes, 2nd edn, pp. 3416-3487. Edited by A. Balows, H. G. Trüper, M. Dworkin, W. Harder \& K.-H. Schleifer. Berlin: Springer-Verlag.

Reichenbach, H. \& Höfle, G. (1999). Myxobacteria as producers of secondary metabolites. In Drug Discovery from Nature, pp. 149-179. Edited by S. Grabley \& R. Thiericke. Berlin, Heidelberg: Springer-Verlag.

Reichenbach, H., Lang, E., Schumann, P. \& Spröer, C. (2006). Byssovorax cruenta gen. nov., sp. nov., nom. rev., a cellulosedegrading myxobacterium: rediscovery of 'Myxococcus cruentus' Thaxter 1897. Int J Syst Evol Microbiol 56, 2357-2363.

Rosenberg, E. \& Varon, M. (1984). Antibiotics and lytic enzymes. In Myxobacteria: Development and Cell Interactions, pp. 109-127. Edited by E. Rosenberg. New York: Springer-Verlag. 
Saitou, N. \& Nei, M. (1987). The neighbor-joining method: a new method for reconstructing phylogenetic trees. Mol Biol Evol 4, 406-425.

Sanford, R. A., Cole, J. R. \& Tiedje, J. M. (2002). Characterization and description of Anaeromyxobacter dehalogenans gen. nov., sp. nov., an aryl-halorespiring facultative anaerobic myxobacterium. Appl Environ Microbiol 68, 893-900.

Schlegel, H. G. (1992). Allgemeine Mikrobiologie, 7th edn. Stuttgart: Thieme Verlag.

Shimelis, O. \& Giese, R. W. (2006). Nuclease P1 digestion/highperformance liquid chromatography, a practical method for DNA quantitation. J Chromatogr A 1117, 132-136.

Shimkets, L. J. \& Woese, C. R. (1992). A phylogenetic analysis of the myxobacteria: basis for their classification. Proc Natl Acad Sci U S A 89, 9459-9463.

Shimkets, L. J., Dworkin, M. \& Reichenbach, H. (2006). The myxobacteria. In The Prokaryotes: a Handbook on the Biology of Bacteria, 3rd edn, vol. 7, pp. 31-115. Edited by M. Dworkin,
S. Falkow, E. Rosenberg, K.-H. Schleifer \& E. Stackebrandt, New York: Springer.

Spröer, C., Reichenbach, H. \& Stackebrandt, E. (1999). The correlation between morphological and phylogenetic classification of myxobacteria. Int J Syst Bacteriol 49, 1255-1262.

Stackebrandt, E. \& Liesack, W. (1993). Nucleic acids and classification. In Handbook of New Bacterial Systematics, pp. 152-189. Edited by M. Goodfellow \& A. G. O’Donnell. London: Academic Press.

Turner, S., Pryer, K. M., Miao, V. P. W. \& Palmer, J. D. (1999). Investigating deep phylogenetic relationships among cyanobacteria and plastids by small subunit rRNA sequence analysis. $J$ Eukaryot Microbiol 46, 327-338.

Weissman, K. J. \& Müller, R. (2010). Myxobacterial secondary metabolites: bioactivities and modes-of-action. Nat Prod Rep 27, 1276-1295.

Wenzel, S. C. \& Müller, R. (2009). The biosynthetic potential of myxobacteria and their impact in drug discovery. Curr Opin Drug Discov Devel 12, 220-230. 